\title{
MODEL PEMBELAJARAN NONDIRECTIVE UNTUK MENINGKATKAN KEMAMPUAN BERBICARA DAN KEPERCAYAAN DIRI PESERTA DIDIK
}

\author{
M. Ali Rajai ${ }^{1}$ \\ Vismaia S. Damaianti ${ }^{2}$
}

\begin{abstract}
ABSTRAK
Pembelajaran yang masih bersifat pemindahan isi melatarbelakangi rendahnya kemampuan berbicara dan kepercayaan diri peserta didik dalam pembelajaran bahasa indonesia. Penelitian ini bertujuan untuk mengetahui kendala dan kesulitan peserta didik dan guru dalam pembelajaran, mengetahui rancangan pembelajaran dan rancangan perbaikan pembelajaran, serta mengetahui hasil belajar peserta didik setelah melaksanakan pembelajaran berbasis model nondirective untuk meningkatkan kemampuan berbicara dan kepercayaan diri peserta didik. Penelitian yang dilakukan merupakan penelitian tindakan kelas dengan subjek penelitian kelas IV SDN Rancabolang Kota Bandung. Instrumen yang digunakan dalam penelitian ini adalah tes unjuk kerja dan tes otentik berupa lembar kerja siswa. Data hasil penelitian disajikan dari hasil prasiklus, siklus I dan siklus II secara deskriptif. Dari deskripsi tersebut dapat dilihat peningkatan kemampuan dan hasil belajar peserta didik dari mulai prasiklus, siklus I dan siklus II. Berdasarkan hasil analisis data ditarik kesimpulan bahwa kemampuan berbicara dan kepercayaan diri peserta didik meningkat setelah melakukan pembelajaran berbasis model nondirective.
\end{abstract}

Kata kunci: Model nondirective, kemampuan berbicara, kepercayaan diri

\section{A. PENDAhuluan}

Bahasa merupakan bagian penting dalam kehidupan bermasyarakat. Penggunaan bahasa yang baik menunjukkan jati diri masyarakat yang baik. Agar dapat menggunakan bahasa yang baik tentu harus memiliki kemampuan berbahasa yang baik pula. Kemampuan berbahasa tidak muncul dengan sendirinya, tetapi merupakan sebuah proses sehingga pada akhirnya setiap orang mampu dan terampil berbahasa dengan baik. Kemampuan berbahasa akan memudahkan setiap orang untuk berkomunikasi dengan orang lain karena kemampuan berbahasa sering sekali disebut sebagai kemampuan berkomunikasi, dan dalam berkomunikasi tentunya menggunakan bahasa sebagai media utama. Kemampuan berkomunikasi inilah yang kemudian berkembang seiring dengan perkembangan setiap individu sehingga mampu menemukan jati dirinya.

Kemampuan berkomunikasi dapat dikelompokkan berdasarkan aspekaspek kemampuan bahasa, yaitu: menyimak, berbicara, membaca dan menulis. Urutan itu menggambarkan proses pemerolehan bahasa di mana setiap orang akan menyimak terlebih dahulu suara atau bunyi yang didengarnya kemudian mencoba untuk menirukannya (berbicara) dan sampailah pada tahap membaca dan menulis. Kemampuan menyimak adalah kemampuan bahasa yang relatif paling mudah

\footnotetext{
${ }^{1}$ Mahasiswa PPs UPI Bandung

${ }^{2}$ Dosen Universitas Pendidikan Indonesia
} 
diikuti dengan kemampuan berikutnya, yaitu berbicara. Brown (2007 hlm. 6) menyatakan bahwa bahasa adalah keterampilan khusus yang kompleks, berkembang dalam diri anak-anak secara spontan, tanpa usaha sadar atau instruksi formal, dipakai tanpa memahami logika yang mendasarinya. Pada bagian lain Ron Scollon dalam Brown (2007 hlm. 6) menyebutkan bahwa bahasa bukanlah sesuatu yang datang dalam unit-unit yang dikemas rapi, tetapi merupakan sebuah fenomena yang melibatkan banyak faktor, kompleks dan senantiasa berubah.

Salah satu aspek yang menjadi tolok ukur kemampuan berbahasa adalah berbicara. Berbicara merupakan salah satu bentuk komunikasi dalam berbahasa, kegiatan berbicara ini tidak hanya diperlukan pada saat melakukan pendidikan formal, lebih dari itu keterampilan berbicara sangat penting dalam kehidupan bermasyarakat. Dengan demikian, di sekolah sebagai lembaga formal diperlukan pembelajaran yang mempertimbangkan aspek perkembangan potensi, kreativitas dan percaya diri peserta didik dalam berbicara. Keterampilan berbicara memerlukan sejumlah potensi pendukung di mana untuk mencapainya diperlukan kesungguhan, kemauan keras, belajar dan berlatih secara terus menerus. Untuk menciptakan iklim atau budaya berbicara yang baik maka akan mendorong seseorang menjadi lebih kreatif, aktif, dan cerdas. Hal ini terjadi karena untuk mempersiapkan sebuah pembicaraan yang baik, sejumlah komponen harus dikuasai, mulai dari hal-hal yang sederhana seperti memilih kata, merangkai kata menjadi sebuah kalimat, sampai kepada menuangkan pemikiran-pemikiran dalam diri setiap orang secara lisan.

Peserta didik menganggap kemampuan berbicara hanya sekedar mampu mengucapkan kata-kata atau kalimat semata dengan suara yang mampu didengar oleh dirinya dan orang lain sehingga memandang tidak perlu mengetahui konsepkonsep dasar kemampuan berbicara itu sendiri. Dari cara pandang itulah maka muncul sikap meremehkan pembelajaran bahasa Indonesia. Bahasa Indonesia di sekolah dasar hanya identik dengan membaca lancar dan menulis rapi maka dianggap sudah mampu menguasai mata pelajaran bahasa Indonesia. Lebih parahnya lagi hal ini didukung oleh pola pikir pendidik yang menganggap bahwa di sekolah dasar anak sudah cukup dengan mampu membaca dan menulis. Tidaklah mengherankan ketika pendidik mulai mengubah konsep pembelajaran bahasa Indonesia maka peserta didik mengalami kesulitan dan tidak percaya diri untuk mengikutinya. Selain itu metode pembelajaran yang monoton, kurangnya stimulus dan motivasi yang diberikan oleh guru, kurang bervariasinya teknik pembelajaran serta minimnya sumber belajar menjadi kendala lain bagi peserta didik dalam meningkatkan kemampuan berbicaranya.

Kendala dan kesulitan peserta didik ini tidak terlepas dari peran guru sebagai pendidik. Tidak sedikit guru sekolah dasar terutama kelas tinggi (IV-VI) memiliki pola berpikir seragam yang menyatakan bahwa di sekolah dasar cukup mampu membaca dan menulis saja, sehingga di kelas tersebut peserta didik hanya diberikan bacaan-bacaan berupa teks dan soal-soal. Guru tidak memperhatikan bahwa dari usia perkembangan kelas IV-VI anak sudah mampu berpikir operasional konkret. Mereka membutuhkan pembelajaran yang realistis dengan kehidupan. Teks bacaan tidak melulu fiktif tapi sudah harus bergeser pada ranah nyata sesuai dengan keadaan yang dialaminya. Kondisi ini menjadi kesulitan tersendiri bagi peneliti karena peserta didik sudah terjejali oleh budaya belajar bahasa Indonesia yang kurang berkesan. Hal ini diperparah oleh sistem yang 
dibuat penyelenggara pendidikan dalam hal ini satuan pendidikan yang menganggap bahwa pendidikan diselenggarakan untuk kepentingan penyelenggara bukan untuk kepentingan peserta didik, sehingga pemerolehan nilai yang tinggi menjadi orientasi mutlak yang menjadi tolok ukur keberhasilan penyelenggara pendidikan, mereka seolah lupa bahwa makna utama pendidikan terletak pada proses bukan pada hasil akhir. Pola pikir guru yang mengajar dengan berorientasi pada pemindahan isi (content transmission) sehingga aspek afektif cenderung terabaikan, guru mengalami kesulitan dalam mengajar karena kurangnya perencanaan yang matang akibat dari tidak jelasnya tujuan pokok mengajar, sehingga masih banyak mereduksi teks (buku acuan/ sumber) yang ada dengan alasan takut salah langkah. Padahal buku panduan yang disediakan oleh pemerintah hanyalah sebagai sumber atau standar minimal yang harus dikuasai, selebihnya guru harus mampu menggali sendiri kemampuannya dengan bukubuku dan sumber-sumber belajar yang lain. Kendala lainnya adalah belum adanya media pembelajaran untuk kompetensi dasar berbicara dan masih kurangnya buku sumber untuk meningkatkan kemampuan berbicara.

Dari kendala-kendala dan kesulitan yang dialami oleh peserta didik dan guru itulah maka penulis mencoba untuk melakukan penelitian dengan menerapkan pembelajaran berbasis model nondrective untuk meningkatkan kemampuan berbicara dan percaya diri peserta didik di kelas IV sekolah dasar. Pembelajaran berbasis model nondrective ini penulis angkat karena merupakan cara paling mudah bagi peserta didik di kelas IV untuk mengawali kemampuannya dalam berbicara. Dalam prakteknya penulis mencoba untuk menerapkan pembelajaran berbasis model nondirective untuk meningkatkan kemampuan berbicara dan percaya diri peserta didik.

Model nondirective ini merupakan model pengajaran personal yang memiliki beberapa tujuan. Salah satunya adalah menuntun peserta didik untuk memiliki kekuatan mental yang baik dan kestabilan emosi yang memadai sehingga diharapkan mampu melahirkan sikap percaya diri yang pada akhirnya mampu menumbuhkan sikap empati terhadap orang lain. Model ini berasal dari kebutuhan dan aspirasi peserta didik itu sendiri, melibatkan semua peserta didik dalam proses menentukan apa yang akan dikerjakan dan bagaimana mengerjakannya, mengembangkan pemikiran, kreativitas dan ekspresi dalam diri setiap peserta didik.

Beberapa penelitian mengatakan bahwa model pengajaran personal akan meningkatkan prestasi akademik yang berdampak pada psikologi pembelajar. Roebuck, Buhler dan Aspy dalam Joyce (2009 hlm. 366) menyatakan bahwa guru yang mengembangkan model personal sangatlah potensial untuk meningkatkan prestasi peserta didik. Masih menurut Joyce (2009 hlm. 367) model pengajaran personal merupakan materi yang sulit untuk diteliti, karena "proses-proses" pengajaran secara alamiah akan berubah saat peserta didik memiliki kemampuan yang lebih memadai dalam meningkatkan perkembangannya. Namun jika model ini diaplikasikan dengan baik dan benar, maka akan memberikan pengaruh dan hasil yang positif dalam aspek afektif, psikomotor dan kognitif.

\section{B. METODE PENELITIAN}

Penelitian ini merupakan penelitian tindakan yang dilakukan untuk mengetahui peningkatan kemampuan berbicara dan kepercayaan diri peserta didik 
kelas IV SDN Rancabolang 1 Kecamatan Rancasari Kota Bandung. Berdasarkan rancangan yang telah dibuat maka metode penelitian yang digunakan adalah penelitian tindakan kelas yang bertujuan untuk mengidentifikasi permasalahan yang ada di dalam kelas dan memberikan solusi dengan menggunakan model pembelajaran nondirective untuk meningkatkan kemampuan berbicara dan kepercayaan diri peserta didik.

Penelitian Tindakan Kelas (PTK) merupakan ragam penelitian pembelajaran yang berkonteks kelas, dilaksanakan oleh guru untuk memecahkan masalahmasalah pembelajaran, memperbaiki mutu dan hasil pembelajaran, dan mencobakan hal-hal baru dalam pembelajaran untuk peningkatan mutu dan hasil belajar (Dasna 2008 hal.25). Penelitian Tindakan Kelas (PTK) ini dilaksanakan dalam 2 siklus, masing-masing siklus terdiri dari empat tahapan utama kegiatan yaitu: (a) perencanaan tindakan, (b) pelaksanaan tindakan, (c) observasi, dan (d) refleksi. Model pelaksanaan PTK ini menggunakan acuan model siklus PTK yang dikembangkan oleh Kemmis dan McTaggart (Akbar Sa'dun, 2006 hlm. 28) dengan alur atau langkah sebagai berikut:

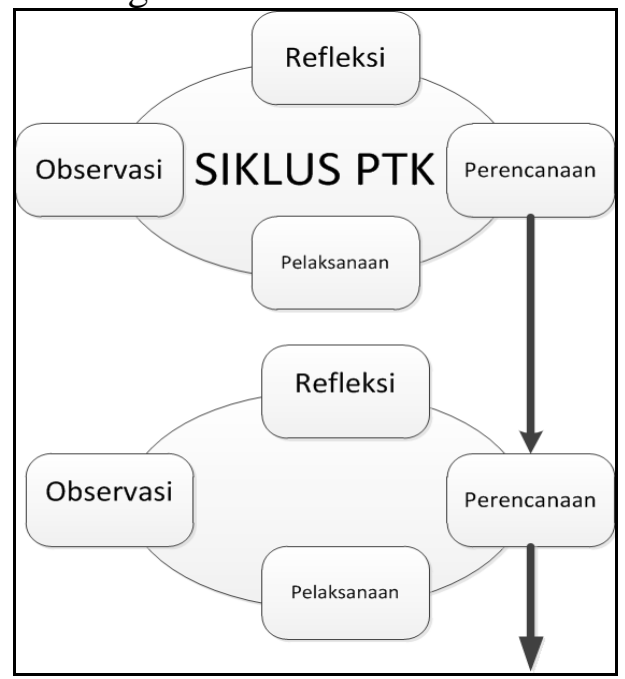

Gambar 1. Siklus Penelitian Tindakan Kelas (PTK) menurut Kemmis dan McTaggart (dalam Akbar Sa’dun, 2010 hlm. 28)

\section{HASIL PENELITIAN}

Peningkatan yang terlihat dari beberapa aspek kemampuan berbicara dan aspek kepercayaan diri peserta didik menunjukkan bahwa pembelajaran berbasis model nondirective sangat potensial untuk mengembangkan kemampuan berbicara dan kepercayaan diri peserta didik. Hasil penelitian tentang kemampuan berbicara dan kepercayaan diri peserta didik terindikasi dari persentase masingmasing aspek kemampuan berbicara dan kepercayaan diri pada tindakan awal (prasiklus) dan setelah tindakan, di mana masing-masing siklus menunjukkan peningkatan, dapat dilihat dari grafik peserta didik yang memperoleh kategori baik sekali dan baik dari setiap siklus. 
Tabel. 1. Peningkatan kemampuan berbicara peserta didik kategori cukup baik, baik dan baik sekali setiap siklus

\begin{tabular}{|l|c|c|c|c|c|c|c|c|c|}
\hline \multirow{3}{*}{ Aspek kemampuan berbicara } & \multicolumn{6}{|c|}{ Presentase (\%) peserta didik setiap siklus } \\
\cline { 2 - 11 } & \multicolumn{2}{|c|}{ Prasiklus } & \multicolumn{3}{c|}{ Siklus I } & \multicolumn{3}{c|}{ Siklus II } \\
\cline { 2 - 10 } & BS & B & C & BS & B & C & BS & B & C \\
\hline Ekspresi & 0 & 26 & 37 & 20 & 37 & 40 & 40 & 47 & 13 \\
\hline Kelancaran & 0 & 30 & 60 & 10 & 50 & 33 & 67 & 27 & 6 \\
\hline Kosakata & 3 & 7 & 70 & 10 & 37 & 30 & 43 & 47 & 10 \\
\hline Intonasi & 0 & 3 & 67 & 0 & 40 & 53 & 20 & 60 & 20 \\
\hline Ketepatan isi dengan topik & 0 & 20 & 54 & 33 & 47 & 20 & 67 & 33 & 0 \\
\hline
\end{tabular}

Dari data pada tabel di atas dapat dilihat bahwa kemampuan berbicara peserta didik pada tahap prasiklus, siklus I dan sikllus II untuk aspek:

1) Ekspresi

Pada tahap prasiklus tidak ada peserta didik yang memperoleh kategori baik sekali, hanya $26 \%$ yang memperoleh kategori baik dan $37 \%$ cukup baik, sisanya masih berada pada kategori kurang. Pada siklus I terdapat $20 \%$ peserta didik yang memperoleh kategori baik sekali, $37 \%$ baik dan $40 \%$ cukup baik, sisanya masih berada pada kategori kurang baik. Pada siklus II sebanyak 40\% peserta didik mendapat kategori baik sekali, $47 \%$ sudah baik dan $13 \%$ cukup baik.

2) Kelancaran

Pada tahap prasiklus tidak ada peserta didik yang memperoleh kategori baik sekali, hanya $30 \%$ yang memperoleh kategori baik dan $60 \%$ cukup baik, sisanya masih berada pada kategori kurang. Pada siklus I terdapat $10 \%$ peserta didik yang memperoleh kategori baik sekali, 50\% baik dan 33\% cukup baik, sisanya masih berada pada kategori kurang baik. Pada siklus II sebanyak 67\% peserta didik mendapat kategori baik sekali, 27\% sudah baik dan $6 \%$ cukup baik.

3) Kosakata

Pada tahap prasiklus ada 3\% peserta didik yang memperoleh kategori baik sekali, hanya 7\% yang memperoleh kategori baik dan $70 \%$ cukup baik, sisanya masih berada pada kategori kurang. Pada siklus I terdapat $10 \%$ peserta didik yang memperoleh kategori baik sekali, 37\% baik dan 30\% cukup baik, sisanya masih berada pada kategori kurang baik. Pada siklus II sebanyak $43 \%$ peserta didik mendapat kategori baik sekali, $47 \%$ sudah baik dan $10 \%$ cukup baik.

4) Intonasi

Pada tahap prasiklus tidak ada peserta didik yang memperoleh kategori baik sekali, hanya 3\% yang memperoleh kategori baik dan $67 \%$ cukup baik, sisanya masih berada pada kategori kurang. Pada siklus I tidak ada peserta didik yang memperoleh kategori baik sekali, $40 \%$ baik dan $53 \%$ cukup baik, sisanya masih berada pada kategori kurang baik. Pada siklus II sebanyak $20 \%$ peserta didik mendapat kategori baik sekali, $60 \%$ sudah baik dan $20 \%$ cukup baik.

5) Keseuaian isi dengan topik

Pada tahap prasiklus tidak ada peserta didik yang memperoleh kategori baik sekali, hanya $20 \%$ yang memperoleh kategori baik dan $54 \%$ cukup baik, 
sisanya masih berada pada kategori kurang. Pada siklus I terdapat $37 \%$ peserta didik yang memperoleh kategori baik sekali, $47 \%$ baik dan $20 \%$ cukup baik, sisanya masih berada pada kategori kurang baik. Pada siklus II sebanyak $67 \%$ peserta didik mendapat kategori baik sekali, 33\% sudah baik.

Hasil penelitian tentang kepercayaan diri peserta didik dapat dilihat pada tabel 2 berikut ini.

Tabel. 2. Peningkatan kepercayaan diri peserta didik kategori cukup baik, baik dan baik sekali setiap siklus

\begin{tabular}{|l|c|c|c|c|c|c|c|c|c|}
\hline \multirow{2}{*}{ Aspek kemampuan berbicara } & \multicolumn{6}{|c|}{ Presentase (\%) peserta didik setiap siklus } \\
\cline { 2 - 10 } & \multicolumn{3}{|c|}{ Prasiklus } & \multicolumn{3}{c|}{ Siklus I } & \multicolumn{3}{c|}{ Siklus II } \\
\cline { 2 - 10 } & BS & B & C & BS & B & C & BS & B & C \\
\hline $\begin{array}{l}\text { Percaya dengan kemampuan } \\
\text { diri sendiri }\end{array}$ & 0 & 26 & 20 & 37 & 50 & 13 & 53 & 47 & 0 \\
\hline Tidak mudah putus asa & 0 & 14 & 23 & 20 & 53 & 27 & 57 & 43 & 0 \\
\hline $\begin{array}{l}\text { Berani menyampaikan } \\
\text { pendapat }\end{array}$ & 0 & 43 & 43 & 37 & 33 & 30 & 47 & 43 & 10 \\
\hline $\begin{array}{l}\text { Mudah berkomunikasi dan } \\
\text { membantu orang lain }\end{array}$ & 0 & 30 & 47 & 27 & 57 & 17 & 50 & 47 & 3 \\
\hline $\begin{array}{l}\text { Berani presentasi di depan } \\
\text { kelas }\end{array}$ & 0 & 37 & 63 & 13 & 50 & 37 & 60 & 40 & 0 \\
\hline
\end{tabular}

Dari data pada tabel 2 dapat dilihat bahwa kemampuan berbicara peserta didik pada tahap prasiklus, siklus I dan siklus II untuk aspek:

1) Percaya dengan kemampuan diri

Pada tahap prasiklus tidak ada peserta didik yang memperoleh kategori baik sekali, hanya $26 \%$ yang memperoleh kategori baik dan $20 \%$ cukup baik, sisanya masih berada pada kategori kurang. Pada siklus I terdapat $37 \%$ peserta didik yang memperoleh kategori baik sekali, $50 \%$ baik dan $13 \%$ cukup baik, sisanya masih berada pada kategori kurang baik. Pada siklus II sebanyak 53\% peserta didik mendapat kategori baik sekali, $47 \%$ sudah baik.

2) Tidak mudah putus asa

Pada tahap prasiklus tidak ada peserta didik yang memperoleh kategori baik sekali, hanya $14 \%$ yang memperoleh kategori baik dan $23 \%$ cukup baik, sisanya masih berada pada kategori kurang. Pada siklus I terdapat $20 \%$ peserta didik yang memperoleh kategori baik sekali, 53\% baik dan $27 \%$ cukup baik, sisanya masih berada pada kategori kurang baik. Pada siklus II sebanyak 57\% peserta didik mendapat kategori baik sekali, $43 \%$ sudah baik.

3) Berani menyampaikan pendapat

Pada tahap prasiklus untuk aspek berani menyampaikan pendapat tidak ada peserta didik yang memperoleh kategori baik sekali, $43 \%$ yang memperoleh kategori baik dan $43 \%$ cukup baik, sisanya masih berada pada kategori kurang. Pada siklus I terdapat $37 \%$ peserta didik yang memperoleh kategori baik sekali, $33 \%$ baik dan $30 \%$ cukup baik, sisanya masih berada pada kategori kurang baik. Pada siklus II sebanyak $47 \%$ peserta didik mendapat kategori baik sekali, $43 \%$ sudah baik dan $10 \%$ cukup baik.

4) Mudah berkomunikasi dan membantu orang lain 
Pada tahap prasiklus, untuk aspek mudah berkomunikasi dan membantu orang lain tidak ada peserta didik yang memperoleh kategori baik sekali, 39\% yang memperoleh kategori baik dan $47 \%$ cukup baik, sisanya masih berada pada kategori kurang. Pada siklus I terdapat $27 \%$ peserta didik yang memperoleh kategori baik sekali, $57 \%$ baik dan $17 \%$ cukup baik, sisanya masih berada pada kategori kurang baik. Pada siklus II sebanyak $50 \%$ peserta didik mendapat kategori baik sekali, $47 \%$ sudah baik dan 3\% cukup baik.

5) Berani presentasi di depan kelas

Pada tahap prasiklus, untuk aspek berani presentasi di depan kelas tidak ada peserta didik yang memperoleh kategori baik sekali, 37\% yang memperoleh kategori baik dan 63\% cukup baik, sisanya masih berada pada kategori kurang. Pada siklus I terdapat $13 \%$ peserta didik yang memperoleh kategori baik sekali, $50 \%$ baik dan $37 \%$ cukup baik, sisanya masih berada pada kategori kurang baik. Pada siklus II sebanyak $60 \%$ peserta didik mendapat kategori baik sekali, $40 \%$ sudah baik.

\section{Pembahasan}

Kegiatan pembelajaran berbasis model nondirective dapat dilakukan untuk merangsang peserta didik agar dapat mengikuti instruksi-instruksi peserta didik dalam mengungkapkan apa yang dirasakannya secara konkret. Gagasan dan pendapat yang muncul dari peserta didik kemudian melecut kepercayaan diri mereka pada saat berbicara di depan kelas. Hal ini sejalan dengan teori perkembangan operasional konkret di mana anak-anak bisa menggunakan berbagai operasi mental, seperti penalaran, memecahkan masalah-masalah konkret (nyata). Anak-anak pada usia ini dapat berpikir dengan logis karena mereka tidak terlalu egosentris dari sebelumnya dan dapat mempertimbangkan banyak aspek dari situasi (Papalia dkk, 2009 hlm. 443).

Kegiatan pembelajaran adalah suatu proses komunikasi yang dilakukan oleh guru dan peserta didik, akan tetapi penyampaian materi dalam kegiatan pembelajaran yang dilakukan oleh guru sering kali terjadi kesalahpahaman yang dapat membuat anak bingung. Anak bisa salah mengartikan apa yang disampaikan oleh guru. Sebaliknya ketika guru dalam menyampaikan materi kurang tepat pada saat pembelajaran, maka anak akan mengalami kesulitan dalam menerima pembelajaran yang sedang disampaikan oleh guru. Dalam kondisi tertentu ada pula peserta didik yang memiliki aktivitas terbatas karena hal-hal yang dialaminya di luar sekolah. Hal ini membuat guru harus semakin peka bahwa peserta didik tidak bisa disamaratakan.

Ada kalanya beberapa peserta didik membutuhkan hubungan personal yang lebih khusus, di sinilah guru berperan sebagai konselor untuk membimbing peserta didik agar dapat berada pada situasi yang memungkinkan untuk mengikuti pembelajaran. Sejalan dengan fokus penggunaan model pengajaran tak terarah ini untuk memberi nuansa lain dalam pengajaran, untuk menjaga dan mempertahankan kerangka berpikir peserta didik, menjaga pusat perkembangan diri mereka, serta membantu mereka mengatasi masalah-masalah pembelajaran. Ketika peserta didik sudah mampu menyampaikan gagasan atau pendapatnya maka muncul rasa percaya diri dalam dirinya. Lebih besar rasa percaya diri itu muncul ketika peserta didik mampu tampil di depan kelas memaparkan hasil diskusi dan karangannya dipresentasikan di depan teman-temannya. Hal ini 
sejalan dengan pendapat Bandura (1977, dalam Hurlock, 1999) self confident adalah suatu keyakinan seseorang untuk mampu berperilaku sesuai dengan harapan dan keinginannya. Orang yang dikatakan memiliki kepercayaan diri adalah orang yang puas dengan dirinya. Seseorang yang mampu melakukan kegiatan yang disukainya kemudian mampu mengungkapkannya kepada orang lain maka muncul kepercayaan dalam diri peserta didik tersebut.

\section{E. SIMPULAN}

Pembelajaran berbasis model nondirective ini dirancang sebagai salah satu cara untuk memberikan penyegaran. Model ini tidak memaksa peserta didik atau pendidik untuk melakukan sesuatu yang formal. Model ini lebih menekankan pada hubungan antar personal di mana setiap peserta didik bisa melakukan hubungan yang baik dengan peserta didik yang lain atau pun dengan guru. Ketika peserta didik melakukan kegiatan yang disukainya maka di situ muncul rasa senang terhadap apa yang dilakukannya. Ketika perasaan senang ini sudah muncul maka apapun yang dilakukan oleh peserta didik tidak akan menjadi beban. Perasaan inilah yang terus dijaga dalam kegiatan pembelajaran berbasis model nondirective.

Perlu disadari bahwa dalam praktiknya tidak semua orang atau anak dalam sebuah komunitas merasakan hal yang sama, dari sanalah maka muncul ide Pembelajaran berbasis model nondirective ini, ketika ada beberapa peserta didik yang mungkin saja dalam kondisi tertentu memiliki kesulitan atau permasalahan yang membentur faktor psikisnya yang bisa menyebabkan hilanganya rasa kepercayaan diri, maka model nondirective ini memberikan keleluasaan kepada guru untuk melakukan bimbingan atau konseling secara personal dengan peserta didik, sehingga peserta didik tidak merasa terasingkan dari dunianya dan bahkan sebaliknya merasa diakui ketika guru merangkulnya dengan bimbingan atau hubungan personal.

\section{DAFTAR RUJUKAN}

Akbar Sa'dun (2010). Instrumen Perangkat Pembelajaran. Bandung. Remaja Rosdakarya

Brown, H.Douglas. (2007). Prinsip Pembelajaran dan Pengajaran Bahasa, Edisi

Kelima. Jakarta: Kedutaan Besar Amerika Serikat di Jakarta.

Dasna, (2008), Pembelajaran Dengan Model Siklus Belajar (Learning Cycle), Malang, Jurusan Kimia FMIPA UM.http://massofa.wordpress.com /2008/01/06/pembelajaran-dengan-modelsiklus-belajar-learning-cycle/ Tanggal akses 28 Februari 2015

Hurlock, B.E. (1999). Psikologi Perkembangan: Suatu Pendekatan Sepanjang

Rentang Kehidupan. Ed. 5. Jakarta: Erlangga; 1999

Joyce, Bruce, dkk. (2009). Models of Teaching.London: Allyn and Bacon. (Indonesia version) Yogyakarta: Pustaka Pelajar

Papalia, Olds dan Feldman. (2009). Human Development. Perkembangan manusia. Buku 1 Edisi 10. Jakarta: Salemba Humanika 